TTR

Traduction, terminologie, rédaction

\title{
Agency, Patronage and Power in Early Modern English Translation and Print Cultures: The Case of Thomas Hawkins
}

\section{Marie-France Guénette}

Volume 29, numéro 2, 2e semestre 2016

Translation and Power: Countertactics

La traduction et le pouvoir : la contre-tactique

URI : https://id.erudit.org/iderudit/1051017ar

DOI : https://doi.org/10.7202/1051017ar

Aller au sommaire du numéro

\section{Éditeur(s)}

Association canadienne de traductologie

ISSN

0835-8443 (imprimé)

1708-2188 (numérique)

Découvrir la revue

\section{Citer cet article}

Guénette, M.-F. (2016). Agency, Patronage and Power in Early Modern English Translation and Print Cultures: The Case of Thomas Hawkins. TTR, 29(2), 155-176. https://doi.org/10.7202/1051017ar

\section{Résumé de l'article}

À la cour anglaise de la reine consort Henriette Marie (1625-1642), la traduction était utilisée comme outil politique en partie pour imposer l'héritage linguistique, culturel et catholique de la reine sur l'Angleterre calviniste. La reine jouait un rôle central comme mécène des arts et agente des relations anglo-françaises, et de nombreux traducteurs lui dédicaçaient des oeuvres pour gagner sa faveur. Je m'intéresse aux " agents traduisants " (Buzelin, 2005), c'est-à-dire aux traducteurs, imprimeurs, et mécènes qui opéraient dans les réseaux politiques, religieux et littéraires de la cour. Je m'appuie sur des travaux sur les aspects culturels et idéologiques de la traduction dans la culture de cour des Stuart et sur des études récentes sur les traductions imprimées en Angleterre prémoderne. J'étudie le mécénat, la production littéraire et la circulation des textes; puis je sonde les réseaux politiques, sociaux, religieux et les réseaux de l'imprimé liés à la production de traductions à la cour de la reine. J'analyse des traductions de catalogues numériques (Early English Books Online, Renaissance Cultural Crossroads, Cultural Crosscurrents in Stuart and Commonwealth Britain) ainsi que les paratextes de traductions dédicacées à Henriette Marie en m'appuyant sur des données de Six Degrees of Francis Bacon et du Oxford Dictionary of National Biography. Dans cet article, je présente le cas de Thomas Hawkins, un agent traduisant clé des réseaux transnationaux catholiques de l'imprimé dont les traductions de La Cour Sainte du jésuite Nicolas Caussin se sont fait une place dans les réseaux sociaux et littéraires de la reine. Je situe Hawkins dans son contexte politique et idéologique et je montre comment il a promu de la littérature dévotionnelle catholique à titre d'agent de traduction, de culture et d'idéologie. Le cas de Hawkins illustre comment l'agentivité, le mécénat et le pouvoir s'unissent dans la culture des traductions imprimées en Angleterre prémoderne.
Ce document est protégé par la loi sur le droit d'auteur. L’utilisation des services d'Érudit (y compris la reproduction) est assujettie à sa politique d'utilisation que vous pouvez consulter en ligne.

https://apropos.erudit.org/fr/usagers/politique-dutilisation/ 


\title{
Agency, Patronage and Power in Early Modern English Translation and Print Cultures: The Case of Thomas Hawkins
}

\author{
Marie-France Guénette
}

Université de Montréal

\begin{abstract}
At the English court of Queen consort Henrietta Maria (1625-1642), translation was used as a political tool, partly to impose the queen's linguistic, cultural and Catholic heritage on Calvinist England. The queen played a pivotal role as a patron of the arts and an agent of Anglo-French cultural relations, and many translators dedicated texts to her in the hopes of winning her favour. This article focuses on "translating agents" (Buzelin, 2005), i.e. translators, printers and patrons, operating in the political, religious and literary networks in and around the Queen's court. My research draws on scholarship on the cultural and ideological aspects of translation in Stuart Court culture and builds on recent studies on the intersection between translation and print in early modern Europe. I study patterns of patronage, literary production, and text circulation; and I probe the political, social, religious, and print networks involved in the production of translations associated with the Queen's court, and extending well beyond its social or geographical boundaries. I examine translations using digital catalogues (Early English Books Online, Renaissance Cultural Crossroads, Cultural Crosscurrents in Stuart and Commonwealth Britain), and conduct paratextual analyses of translations dedicated to Henrietta Maria. In this article, I study translator Thomas Hawkins by using data from Six Degrees of Francis Bacon and the Oxford Dictionary of National Biography. Hawkins was a key translating agent who operated in transnational Catholic print networks and whose translations of Jesuit Nicolas Caussin's La Cour Sainte found their way into social and literary networks around the Queen's court. I situate Hawkins in the political and ideological contexts of the time and show how he promoted Catholic devotional literature in his capacity as agent of translation, culture and ideology. Hawkins's case illustrates how agency, patronage and power come together in early modern England's culture of printed translations.
\end{abstract}


Keywords: translating agents, political networks, printed translation culture, Queen Henrietta Maria, Thomas Hawkins

\section{Résumé}

À la cour anglaise de la reine consort Henriette Marie (1625-1642), la traduction était utilisée comme outil politique en partie pour imposer l'héritage linguistique, culturel et catholique de la reine sur l'Angleterre calviniste. La reine jouait un rôle central comme mécène des arts et agente des relations anglo-françaises, et de nombreux traducteurs lui dédicaçaient des œuvres pour gagner sa faveur. Je m'intéresse aux «agents traduisants» (Buzelin, 2005), c'est-à-dire aux traducteurs, imprimeurs, et mécènes qui opéraient dans les réseaux politiques, religieux et littéraires de la cour. Je m'appuie sur des travaux sur les aspects culturels et idéologiques de la traduction dans la culture de cour des Stuart et sur des études récentes sur les traductions imprimées en Angleterre prémoderne. J'étudie le mécénat, la production littéraire et la circulation des textes; puis je sonde les réseaux politiques, sociaux, religieux et les réseaux de l'imprimé liés à la production de traductions à la cour de la reine. J'analyse des traductions de catalogues numériques (Early English Books Online, Renaissance Cultural Crossroads, Cultural Crosscurrents in Stuart and Commonwealth Britain) ainsi que les paratextes de traductions dédicacées à Henriette Marie en mappuyant sur des données de Six Degrees of Francis Bacon et du Oxford Dictionary of National Biography. Dans cet article, je présente le cas de Thomas Hawkins, un agent traduisant clé des réseaux transnationaux catholiques de l'imprimé dont les traductions de La Cour Sainte du jésuite Nicolas Caussin se sont fait une place dans les réseaux sociaux et littéraires de la reine. Je situe Hawkins dans son contexte politique et idéologique et je montre comment il a promu de la littérature dévotionnelle catholique à titre d'agent de traduction, de culture et d'idéologie. Le cas de Hawkins illustre comment l'agentivité, le mécénat et le pouvoir s'unissent dans la culture des traductions imprimées en Angleterre prémoderne.

Mots-clés: agents traduisants, réseaux politiques, culture de l'imprimé, reine Henriette Marie, Thomas Hawkins

\section{Introduction}

In 1625, French Princess Henrietta Maria was married to Charles I, and became the queen consort of a powerful Protestant nation and a cultural beacon for long-standing Catholic families of England. Translation was used as a political tool at her English court, notably to impose her linguistic, cultural and Catholic heritage on Calvinist England. Henrietta Maria herself played a pivotal role as a patron of the arts and agent of Anglo-French cultural relations, and many translators dedicated their works to her in the hopes of winning her favour. 
My research focuses on the transnational networks of translators and printers that operated in and around the English court of Queen Henrietta Maria (1625-1642). I study the traces of these networks through the analysis of material print culture, and pay attention to those agents who stand out as major players. This article addresses the notions of agency, power and patronage in translation history and focuses on the translating agents (Buzelin, 2005) - i.e. translators, printers and patrons — that operated in the political, religious and literary networks in and around the English court of Henrietta Maria. My corpus of translations begins in 1625 since this is when Henrietta Maria became queen consort of England and ends in 1642, because this year marks the beginning of the queen's exile in France, where she also established a court following with a new network structure in a different political and cultural setting.

My research draws on scholarship on the cultural and ideological aspects of translation in Stuart Court culture (see Norbrook, 1999; Clarke, 2001) and builds on recent studies of the intersection between translation and print in early modern Europe (see Hosington, 2011; 2015a; 2015b; Coldiron, 2015). I study patterns of patronage (Lefevere, 1992), literary production, and text circulation in the context of Henrietta Maria's English court; and I probe the political, social, religious, and print networks involved in the production of translations associated with her court, and extending well beyond its social or geographical boundaries (Demetriou and Tomlinson, 2015; Belle and Hosington, 2017). My goal is to identify key agents who operated within these networks, and determine what place they held in political, cultural and social spheres, and how they acquired, maintained or lost their position within these circles.

To establish an overview of these networks, I examine translations documented in digital catalogues such as the Renaissance Cultural Crossroads ([RCC] Hosington, 2011), Cultural Crosscurrents in Stuart and Commonwealth Britain ([CCC] Belle and Hosington, 2017), Early English Books Online (EEBO), and the Bibliothèque nationale de France's Gallica. Furthermore, I conduct paratextual analyses of translations, especially those dedicated to Queen consort Henrietta Maria, to King Charles I, or to the royal couple. The culture of printed translations in early modern England has recently drawn interest from experts 
in translation history, book history and even digital humanities (Boutcher, 2015; Hosington, 2015a; 2015b; Silva, 2016; Belle and Hosington, 2017). The study of patronage in this complex historical context is situated at the intersection of these fields, and is a conducive lens for network analysis. Though a dedication in a printed translation is not necessarily proof of patronage, it does indicate a desire for cultural capital, upward mobility, and social climbing. When a dedicatory epistle clearly identifies the prospective reader or dedicatee of the translation, or when a patron's name is indicated in the paratext, this sets the stage for a preliminary network structure. Using these names, relationships and places as preliminary markers of social, political and religious affiliations, I investigate the connections between the translator and the patron or dedicatee. This allows me to reconstruct the political networks around the queen, which are inseparable from Catholic ideological networks, and therefore to identify the main translating agents operating in Catholic print networks and in social and literary networks around the queen's court.

In this article, I validate paratextual and biographical data from the Renaissance Cultural Crossroads Catalogue (RCC) notably by cross-referencing network information documented in the crowdsourcing project Six Degrees of Francis Bacon (6DFB; Warren et al., s.d.) and biographical data located in the Oxford Dictionary of National Biography (ODNB). Correlating these data allows me to uncover key members of the court and establish and explore social connections which have yet to be documented. I use the collected data as a gateway to recreate the cultural and political patronage networks of early modern English translators. In this article, I present the case of Thomas Hawkins, a recusant translator who dedicated his translations of La Cour Sainte to Queen Henrietta Maria. As my research is guided by the notion of agency in translation studies, I will first offer an overview of the contribution that agency and patronage have brought to translation history.

\section{Agency in translation history}

How do we uncover agents whose contribution is relevant to translation history? Finding markers of agency begins with the study of sociohistorical, geographical, political and cultural factors within the vast frame of translation studies. Theoretical works brought about by the cultural turn in translation studies help clarify 
some key elements of textual production, guiding researchers with reflexions on "how a text is selected for translation, [...] what role the translator plays in that selection, what role an editor, publisher or patron plays, what criteria determine the strategies that will be employed by the translator, how a text might be received in the target system" (Bassnett, 1998, p. 123). This inventory of agents and factors with the power to influence the production of texts represents a partial list of research topics that can allow us to uncover political, ideological and cultural issues, as well as the roles that different agents play in the production of translations.

The notion of agency can be used to establish a textual, paratextual and social corpus to help researchers trace translators' thought processes, and definitions of this notion abound in translation studies. Translation sociologist Outi Paloposki works with an expansive definition of agency in her research to analyze fringe data, or what she has come to call the translator's footprints:

If agency is understood as the translator's everyday practices, decisions and even routine chores, such documents as for example drafts, letters and notes provide ample material for study. They contain information on translators' aids, tools, requests, suggestions and refusals, and give clues to their working environments, networks and affiliations, as well as their freedom of choice to decide for themselves on certain issues (or negotiate them with other agents, such as authors, publishers, other translators). (2010, pp. 88-89)

Paloposki's definition of agency is all-encompassing and broad enough to reflect the reality of research in translation history. Her perspective of agency points researchers to new avenues for the exploration of agency markers, and endorses Maria Tymoczko's (2007) call to enlarge translation as a way to emancipate translators. After all, translation historians must frequently cope with serious limitations: deceased participants, partial (or sometimes lost) corpus documentation, risks of anachronistic reasoning of historical events, to name a few. Using a definition of agency that is all-encompassing in scope (such as Paloposki's) as a starting point for network analysis can help translation historians overcome some of the temporal issues related to their corpus.

Translation history has greatly benefited from new articulations of agency in translation studies. Book-, literature- and culture historians have highlighted the importance of translation 
for the study of different types of agents who participated in the production of translations and who, consequently, contributed to the circulation of philosophical, religious and political ideas between European countries during the Renaissance. According to Warren Boutcher:

Book history and cultural history have placed translations at the centre of a mighty and intricate nexus of authors, translators (including intermediary translators), paratextwriters, editors and correctors, censors, printers, booksellers, patrons and readers. $(2015$, p. 23$)$

Boutcher raises essential questions highlighting the relevance of agency in translation studies, notably the universal character of the notion due to its applicability to numerous geographical and temporal contexts, as well as its collective dimension, which is revealed in the individual role of each agent who operates in a production network and who participates in a culture of translation. There is rarely a sole agent, and each person who contributes to the production of a translation has his or her own reasons for doing so. By creating an overview of Renaissance translation cultures, Boutcher stresses the importance of considering all the actors of a network, because any one of them has the potential to be the main agent, the one who determines the choice, approval, production, publication and sale of a translation:

there was a great diversity in the relations of agency within the intricate nexus that brings together authors, translators, editors, printers, booksellers, patrons and readerships. Any of them could be prime mover in the production of a translation. (ibid., p. 37)

The motivations of these agents could be the desire to be known or to gain the approval of a patron, or even to make money. Boutcher gives the example of when Don Quixote, the famous Cervantes character, meets a translator who pays for a printer to publish his translation, but is confronted with the issue of black market book sales. During the Renaissance, printers, stationers and book sellers were suspected of colluding to produce extra copies of books without the permission of the translator, and then selling them at a cut price, essentially profiting from the sale of stolen copies. Though this example is taken from a work of fiction, it reflects the harsh reality of the translation and print industries of the Renaissance. Print agents also worked as marketing masterminds, 
maximizing the use of liminal pages of printed works to promote new translations and engage readers. Andie Silva also highlights the contribution of non-authorial paratexts in historical analysis, asserting that 'paratexts' unique combination of financial and aesthetic value helped develop relationships between agents and readers" (2016, p. 608).

The Renaissance provides rich material for research in translation studies as well as literary and book history, as demonstrated by the numerous recent research projects on early modern English print culture (see Hosington, 2011; Boutcher 2015; Coldiron, 2015; Silva, 2016; Belle and Hosington, 2017). According to Brenda Hosington (2015a), the printed book and the printing press have been at the heart of projects which were spearheaded in part thanks to Eisenstadts' 1979 book The Printing Press as an Agent of Change. Indeed, reflecting on the valuable contribution of the notion of agency, researchers at the intersection between translation studies and book history even acknowledge the agency of material innovations like the printing press. Such is also the case for works that use translation theory and book history for the purpose of inquiring after the literary and social histories of the Renaissance, such as Marie-Alice Belle and Brenda Hosington's research project Translation and the Making of Early Modern English Print Culture (1473-1660), which culminated in the production of the free-access catalogue Cultural Crosscurrents in Stuart and Commonwealth Britain ([CCC] Belle and Hosington, 2017), which is itself dedicated to documenting the paratext of translations into English. By providing paratextual content as well as biographical data on translators, the catalogue helps reconstruct Renaissance print cultures and social networks, and reveals the roles played by agents who had until recently gone unnoticed. Silva also recognizes the importance of the printing press as the core object of study for network analysis of print cultures and agency in Renaissance history, and reminds us of the collaborative nature of all work surrounding the printing press:

The printing press undeniably depended on the collaborative work of multiple agents: not simply printers and booksellers, but also typesetters, woodcutters, binders and papermakers, among others. (2016, p. 607)

Therefore, to arrive at a holistic understanding of early modern translation and print cultures, we must first leverage paratextual 
and biographical data to reconstruct networks of agents, then create profiles of those players who brought about change by re/ translating, re/printing or importing literary works into a given culture.

Though it may not always be specified, case studies in translation history usually follow a microhistoric approach to find meaning in agents who come to light through research. Microhistory is a method of investigating historical facts whereby figures and events which often go unnoticed are brought to the forefront. This approach allows researchers to expand individual case studies to a larger scale, thus shedding light on markers of agency, vaster social and professional networks, and knowledge transmission systems, among others.

$[\mathrm{M}]$ icrohistory claims, explicitly or implicitly, to illuminate more general truths, wider patterns, or at least to draw some analogy to other cases. In the best of circumstances, microhistorical studies reveal in fine-grained detail how larger processes operate, how the case serves as a useful hypothesis for exploring other cases. (Brooks, DeCorse and Walton, 2008, p. 5)

Though constructing a catalogue of printed translations over a period of nearly 200 years constitutes a macrohistorical approach, microhistory is still used in Belle and Hosington's (2017) project to delve into active early modern agents' profiles. The same is true for recent works by Anne Coldiron, particularly her book Printers without Borders (2015), which considers case studies on Renaissance printers and translated texts. According to Coldiron, by analyzing Renaissance textual data from a new perspectivethat is, by studying works which are not necessarily part of the Renaissance literary canon as it is perceived today-we can discover agents whose existence we have ignored until now, or whose role in history was unknown:

Another result of this approach is that we meet not only the usual suspects but those figures, such as printers and translators, who could otherwise too easily be mistaken for peripheral players in literary history. (2015, pp. 283-284)

The agency of translators, printers and patrons can thus be revealed and studied in relation to other descriptive case studies on historical topics. 
Research in sociology of translation, a field which is principally interested in the human factor in translation studies, has expanded the notion of agency and adapted it to the specificities of translation as object and process. In her article "Unexpected Allies" (2005), Hélène Buzelin looks into the role of agents who contribute to the process of producing translations, and she puts forward Bruno Latour's Actor-Network Theory (ANT). "In short, this concept enables us to grasp both the complexity-and nonlinear character - of the translation process, and the hybridity of the translating agent" (Buzelin, 2005, p. 212). Here we discover the importance of interactions between translators and agents who have decision-making power over translations, but who have been ignored in translation studies. Agency in the production of translations clearly applies to more actors than the translator alone. Buzelin sheds light on the multiple facets of what she calls the "translating agent":

the person officially designated as performing the role of translator is not necessarily a single individual and, in any case, this translator is not the only one to translate. In other words, there is a difference between translator and translating agent. (ibid., p. 214).

The translating agent ties in with the works of Susan Bassnett (1998) and André Lefevere (1992) where researchers in translation studies are asked to research patrons, rewriters, creators of anthologies and history manuals, because these agents can play an active role in the promotion and survival of translations. Latour's ANT also reminds us that the study of agency must also take into account the undeniable contribution of institutions:

La notion de société faite d'humains est remplacée par celle de collectif produit par des humains et des non humains [...]. La contribution des non humains ne peut plus être ignorée ou minimisée par les sciences sociales car les investissements croissants dans la recherche et dans l'innovation technique en augmentent le nombre de manière quasi exponentielle. (Callon, 2006, p. 272)

When studying the place of translators in the translation process, researchers must therefore take into account the numerous translating agents or mediators who influence the final product. Buzelin summarizes the potential contribution of Latour's ANT 
to translation studies and in so doing, she points to avenues for future research in the field:

it will enable us to acquire data to which translation theorists have rarely had access so far, namely data on the multiple mediators potentially involved in the translation process, including the way they make or explain their decisions $[\ldots]$, and the strategies by which they negotiate their place in the process, convince others to participate, etc. $(2005$, p. 215)

The strengths of the ANT and the innovative nature of the proposed reflexion reveal its valuable contribution to research in translation studies. Descriptive, cultural and historical approaches to translation studies are well suited for the study of translating agents, and benefit from the debates arising from research in sociology of translation. In summary, textual analysis does not suffice to establish a comprehensive understanding of who did what to a given text at a given moment and for what reasons. Buzelin's (2005) notion of translating agent hints at numerous ways to analyze translation, and it is beneficial for the study of active agents in translation history.

\section{Patronage and translation}

Translation studies are often invested in the search for norms and agency, and this is also true of case studies in translation history. The cultural turn in translation studies contributed greatly to the expansion of the field, as demonstrated by Lefevere's research on the agents and factors that influence the production of texts. In Translation, Rewriting and the Manipulation of Literary Fame, Lefevere clarified what a patron is and defined the meaning of patronage for translation studies:

Patronage can be exerted by persons [...] by groups of persons, a religious body, a political party, a social class, a royal court, publishers, and last but not least, the media, both newspapers and magazines and larger television corporations. (1992, p. 15)

In so doing, Lefevere directed the attention of researchers to one of the principal actors in the production of translations: the patron, the one who requests translations or inspires translators to produce a translation. Lefevere also shed light on the role of patrons: "Patrons try to regulate the relationship between the literary system and the other systems, which, together, make up 
a society, a culture" (ibid.). Richard McCabe has since refined the concept of patronage for the study of culturally and historically specific early modern English printed translations, writing:

Patronage $[\ldots]$ is largely a matter of reception, of inherited ideals, idioms, and aspirations constantly adjusted to emergent circumstances, of creative mimesis as a strategy for self-promotion, and even survival. (2016, p. 10)

McCabe also studied how translators, printers and book sellers sought patronage to further expand their opportunities for upward mobility, and in so doing, he identified various networks of possibilities for translators:

The networks through which patronage was sought were extremely diverse: access to influence might be institutional (through schools, universities, Inns of Court, or guilds), regional (tapping into ancestral loyalties to local magnates), religious (engaging with denominational or sectarian sympathies), familial (embracing extended groupings of clients and dependants as well as blood kin), or factional (promoting or exploiting local or national divisions). (ibid., p. 4)

Furthermore, in his seminal work, Lefevere (1992) drew parallels between patronage and institutions that promote and control various ideologies such as religious beliefs, cultural values and nationalist movements. By controlling workflow, patrons and institutions maintain political, cultural, religious and ideological power and assert their dominance over the people they govern or to whom they allow access to education. Lefevere's work sparked an interest in matters of agency and power that underscore the relevance of patronage and the scope of the cultural turn in translation studies.

The case of Thomas Hawkins illustrates how agency, patronage and power come together in early modern England's culture of printed translations. In my study of Hawkins' translation of La Cour Sainte, I adopt a historicist perspective, situating the work in the political and ideological contexts of the time, thus showing the ways in which this translator promoted Catholic devotional literature in his capacity as agent of translation, culture and ideology. In so doing, I will situate him as a recusant translator within the mediating network of transnational communities of readers. 


\section{Thomas Hawkins: translating agent extraordinaire}

Thomas Hawkins (bap. 1575- d. 1640?) was an early modern English translator who operated in transnational Catholic print networks and employed his agency to acquire patronage. $\mathrm{He}$ is known for his successful Englishing of La Cour Sainte, a fivevolume spiritual guidebook that emphasizes the importance of the Christian institution, and that found its way into social and literary networks around Queen Henrietta Maria's court. The first volume of the treatise, written in 1624, was entitled La cour sainte: ou, L'institution chrestienne des grands, avec les exemples de ceux qui dans les cours ont fleury en saincteté, and was written by the French Jesuit Nicolas Caussin (1583-1631) ${ }^{1}$. The original work was produced and sold by the Paris Catholic printer and bookseller Sébastien Chappelet. We know from Jesuit records that the King of France, Louis XIII, had asked Caussin to be his confessor,

1. All French editions of La Cour sainte were written by Caussin; I have yet to compile a complete list of all known editions. According to Guy Thuillier (1998), the Bibliothèque nationale de France $(\mathrm{BnF})$ holds a copy of the original 1624 edition, and for the purposes of his article, Thuillier consulted editions from 1624, 1642, 1658 and 1664. Gallica, the BnF's catalogue, offers access to digitised versions of the 1653 and 1668 editions, each divided between two books marked tome 1 and tome 2. Barbara Piqué (2007) quotes from French editions published in 1624, 1625, 1627, 1636, 1637 (tome III)-1638 (tomes I, II, IV), 1639-1641 (reprint of 1637-1638 edition), 1643, 1645, 1647 (two editions that year). As for the English translations, EEBO documents eight editions which were respectively published in 1626 (the first tome, dedicated to Queen Henrietta Maria), 1631 (the second tome, dedicated to Edward Sackville, Lord Chamberlain to the Queen), 1634 (reedition of tome 1 with dedication to Henrietta Maria, reedition of tome 2 with dedication to Lady Frances Countess of Portland and another dedication to Edward Sackville, plus first English translation of the third tome with no additional dedicatory epistle by the translator), 1638 (titled The Holy Court and the Command of Reason over the Passions and dedicated to the Princess Duchesse of Buckingham). These first four editions were translated solely by Thomas Hawkins. The subsequent 1650 edition, published after Hawkins's death, is marked as translated by Thomas Hawkins and "others". The title page advertises that the book is in five tomes, with "the fifth, now first published in English, and much augmented according to the last edition of the authour" (Hawkins and Others, 1650). In the 1650 edition, the first tome is dedicated to Henrietta Maria, the second to Edward Sackville, the third to Ladie Frances, Countess of Portland, the fourth to the Princess Duchess of Buckinham, and the fifth tome not boasting either dedicatory epistle nor translator name, though including a notice to the reader. The final three English editions are from 1663, 1664, and 1678, and they all seem to be a replicas of the 1650 edition. 
but Caussin apparently declined because it was the right thing to do (that is, "parce qu'il se comportait comme un homme de bien” [De Backer, De Backer and Sommervogel, 1869, p. 1143]). Nevertheless, Caussin dedicated the work to the king, praising the king's devotion to Catholicism and informing him that he had the ability to enforce the virtuous laws put forth in the treatise:

AV ROY.

SIRE,

Ce traité de la Sainteté des Cours, ne peut sortir au jour que tous les rayons de vostre Majesté, que Dieu a choisie pour sanctifier son Royaume par l'exemple de ses vertus, \& par l'autho-rité de ses Loix. [...] Comme votre Majesté, SIRE, de ses plus tendres années a monstré auoir en horreur l'impiété [...] cela me fait dire qu'elle a de grands moyens de faire la Cour Sainte en essence, que ma plume ne peut faire qu'en papier. (Caussin, sig. iiij)

Like most translators, Thomas Hawkins chooses a different dedicatee for his translation of the first volume titled The Holy Court or The Christian Institution of Men of Quality. With Examples of those, Who in Court haue flourished in Sanctity. By Nicolas Caussin of the Society of Jesus. Written in French and Translated into English by T.H. At Paris. Anno Dom. M. DC. XXVI. Hawkins's dedicatee, Queen Henrietta Maria, is more suitable to the new context and is one who could offer him protection and patronage, although Hawkins also translates Caussin's dedication following his own dedicatory epistle. My preliminary research shows that while Henrietta Maria was sometimes associated with Charles I in translation dedications, many translations were more directly associated with her own court. Works of devotional literaturemany of which were actually printed in France-were actually personally dedicated to her. Hawkins's version of La Cour Sainte is one of such translations. In his dedicatory epistle addressed "to the most excellent maiesty of Henriette-Maria Queene of Great Brittaine", the translator mentions the religious affiliations of the queen's family, and speaks of her brother's (French King Louis XIII) approval of the literary work that is being presented to her. He writes:

A Court adorned vvith Vertue, and sanctified vvith Piety, is heere (most excellet Queen) 
to Your View presented;

which hauing once already in pure, and natiue colours receyued light, and life from the bright eye of your Royall Brother, vvould gladly at this tyme, in a harsher language, \& ruder garment aduenture your gracious Acceptance. (Hawkins, sigs. 1r-1v)

Here, Hawkins makes use of a clever strategy to make a stronger appeal to Henrietta Maria, as his words allude to Louis XIII's seeming approval of Caussin's work. Moreover, this is reinforced by his translation of the French dedication to Louis XIII and address to the nobles of France immediately following, again no doubt to please the queen.

Hawkins further emphasizes the value of the book for English Catholics, making it clear that his work is intended for the English when he alludes to the queen's radiance and light that will "heate our more Northerne Clime" (the land North of France being England). Also, his use of the word "Heere" can refer both to this work, and to England. In his address, he also illustrates the outcome he wishes for recusant families of England:

Heere shall a Holy Court be found, fairely delineated; nor can I see hovv it vill be in the povver of persons of best Eminence, to plead Ignorance, and pretend inability; they hauing such a Booke to direct them, and such a Queene to follovv.

Lead them vvith alacrity (most Sacred Maiesty,) and may propitious Heauen, so prosper your holy Desires, that the Greatest may haue Matter to imitate, and the vvhole Nation to admire (Hawkins, sigs. 1v 2r).

Clearly, the translator is reinforcing English recusant families' faith in Henrietta Maria to champion the religious cause of Catholics. Much like Caussin's address to the king of France, Hawkins's dedication stresses the queen's ability to defend Catholic virtue at the English court and communicates the discourse of France's Jesuits according to which the queen can lead English Catholics.

Hawkins was a member of a long-standing Catholic family and translated works of Catholic devotional literature, which 
made him an active promoter of Catholic culture at a time when England was a Protestant nation. He used his connections to the Jesuit educational and print networks to publish his works, and dedicated translations to Henrietta Maria to gain notoriety and the consideration of the head of state and Catholic monarch of England. In this historical and political context, dedicating a translation could serve diverse functions (see McCabe, 2016), and it is difficult to designate a single reason for Hawkins's dedicatory epistle in The Holy Court (1626). Hawkins might have been seeking patronage from the queen or members of her court or close circle. $\mathrm{He}$ might also have been looking to make his religious and/or political affiliations known to readers around the queen's court; and then again, he may have been seeking to establish friendships or literary connections among high-standing Catholic courtiers.

When one thinks of a translation from French to English dedicated to a single person, one would immediately assume that the work was translated to eliminate a linguistic or cultural barrier which prevented the dedicatee from reading the original text. However, when Hawkins dedicated The Holy Court to Henrietta Maria, he offered her a translation into English of a French book which was circulating freely and was widely available in France at the time. Perhaps the blatantly Catholic nature of the book made it difficult for the queen to access, which would suffice as an explanation for the production of an English version. Ironically, it is thought that when Hawkins's translation was printed, the queen did not speak much, if any, English (see White, 2006; Harris, 2016). Indeed, during her first few years in England, the queen spent most of her time in the company of her French-speaking courtiers and ladies-in-waiting (Harris, 2016, p. 51). The fact that the queen did not need an English version of La Cour Sainte reaffirms the political dimension of Hawkins's translation project. And though we do not know if Hawkins selected the books he translated, or whether these were assigned to him by friends or patrons, he did translate Catholic devotional literature, which we know the queen was fond of (see Bailey, 2009).

In the paratexts prefacing his translation, Hawkins reveals that he is operating within a transnational community of readers by dedicating his work to the French Henrietta Maria and by translating Caussin's dedication hinting at the approval of the French king and his address to French nobles. They give the work 
an international dimension. The speed at which The Holy Court appeared in England and its place of publication are also an indication that Hawkins was part of a transnational print network, that of the Jesuits. The translator presumably received orders from his Jesuit brother Henry to translate the book, and it was printed in Flanders at the English Jesuit College of St. Omer, two years after the original had begun circulating in France. Two further editions appeared in Rouen in 1634 and 1638, thereby continuing the French-English print network links. The case of La Cour Sainte in English translation therefore illustrates the existence of a transnational network of printed book circulation between England and France, and reveals how French Catholic books came into England through Jesuit networks, were translated and re-exported, only to be re-imported, albeit in "ruder garment", as Hawkins says in his dedication (sig. 1v). Belle and Hosington argue that:

Transnational networks also played an important part in the circulation of forbidden books by and among English Catholic recusants. Many of these were translations, made and printed by exiled Catholic scholars and religious in Douai, Reims and other continental recusant printing centres. Often escaping the traditional channels of book production and circulation, these works were designed to be smuggled into English households, or to contribute to strengthening the Catholic cause in both English and continental Europe. (2017, p. 18)

The Hawkins family is an excellent example of how Catholic writings circulated between France and England through the Jesuit scholars' network. Though Thomas Hawkins had been knighted by James I in 1618, "he and his wife were indicted for recusancy" in 1626, and Hawkins was later said to be "a great papist and harbourer of priests" (Adolph, 2008, n.p.). The RCC catalogue also mentions these crucial religious biographical details concerning Thomas Hawkins and his family, specifying that Thomas was the brother of Jesuit Henry Hawkins, that he had "local indictments for recusancy" (RCC), and that he translated several works for Jesuits. In the ODNB, we discover that his nephew Francis Hawkins, son of his brother John, was also a Jesuit and was known for his translations from a young age (Adolph, 2008). Many social connections between Thomas Hawkins and his peers have been documented in the $6 \mathrm{DFB}$ project thus far, but a 
formal connection between Hawkins and Queen Henrietta Maria has yet to be made. This could mean that though he dedicated his translation to her, he never actually knew her formally. This could also mean that there was indeed a formal social connection between them, but that it has yet to be documented in the project.

Using data from 6DFB, Thomas Hawkins's network shows (with a relationship confidence level $^{2}$ of $40 \%$ ) that he was connected to a large number of social, artistic and political players in early modern England. I have yet to analyze each node of this vast network, but for illustration purposes, I reduced the network by using a relationship confidence level of $60 \%$. The 6DFB project is ongoing and also builds on data crowdsourced from scholars. The project is built on the premise that people need to have met in order for their connection to be documented in the social network. In its initial phases, statistical algorithms were used to survey the information available in the ODNB to determine the likeliness of people having encountered each other. This methodological choice explains why Thomas Hawkins's network is currently quite limited on the 6DFB site. Hawkins's close network is comprised of his brother John, also a translator, and John's son Francis, a translator and Jesuit priest. We also see Henry Hawkins, his brother who was a Jesuit priest in France. Other connections include known Catholic Anne Arundell, who was said to be a "supporter of priests"; and Epiphanius Evesham, a painter and sculptor, also a known Catholic. Robert Codrington

2. On the $6 \mathrm{DFB}$ platform, the "confidence level" of a relationship signifies the "likelihood of a relationship's existence that ranged between 0-never inferred-and 100-always inferred" (Warren et al., 2016, par. 25). The percentages ranging from $40-100 \%$ are considered "possible to certain" (par. 36), and those ranging from 60-100\% are deemed "likely to certain" (par. 37). In lay terms, the percentage qualifies the degree of probability that the two connected people did indeed know each other. The data used in this article was available under the first version of the $6 \mathrm{DFB}$ project. The project was subsequently redesigned, and the updated version became accessible on November 17th 2017. The new version does not allow users to specify the relationship confidence level, but does qualify each documented relationship link as either a "statistical inference" or a "human contribution" to indicate the accuracy of the designated connections (for more information on the different versions, see the $6 \mathrm{DFB}$ blog homepage at http://6dfb.tumblr.com/). It is worthy of mention that though the project was updated, when I verified the relationship data for Thomas Hawkins in July 2018, the only change that had been made to his documented network was the fact that the link between Henry Hawkins and Anne Arundell was qualified as a "human contribution", while others were "statistical inferences". 
was thought to be a Protestant, but after Thomas Hawkins's death, he worked on the 1650 edition of The Holy Court. From research into Thomas Hawkins's close network, we learn that the Hawkins family were also patrons to Catholic artists. Thomas Hawkins's connection to Epiphanius Evesham (1570-1623) in the 6DFB project is clarified in the ODNB biography for Evesham (White, 2004). A known Catholic, Evesham worked in Paris as a sculptor, painter and metal engraver for several years, and upon his return to England, he mainly worked as a tombstone sculptor. In 1618, he designed and produced the tombstone for Thomas Hawkins's parents. We also know that he defied Protestant conventions by featuring sculptures of Christ resurrecting on monuments and tombstones.

\section{Conclusion}

In summary, Thomas Hawkins used translation to develop cultural and political agency, and he exploited Catholic ideologies and networks. He also employed his cultural and political agency when he dedicated The Holy Court to Queen Henrietta Maria and contributed to creating a space for translated French Catholic devotional literature in the queen's court. Indeed, his work as a translator of French literary works marks him as an importer of French culture into England. Hawkins exploited Jesuit connections in his decision to translate devotional literature and Jesuit religious manifestos. Though he was indicted for recusancy, he and his family remained fervent Catholics (Adolph, 2008), which shows the level of their devotion to the Catholic faith. Furthermore, it seems that Hawkins acquired translation material through his access to Jesuit print networks, and in this way, he benefited from Jesuit patronage. Thomas Hawkins was undoubtedly a translating agent, seeing as he operated in the political, religious and literary networks in and around the English court of Queen Henrietta Maria.

Many of the social, political and literary connections between Thomas Hawkins and his peers have yet to be documented and defined. As I pursue my research, I aim to clarify the nature of these relations, and identify other translating agents who operated in and around the English court of Queen Henrietta Maria while also contributing to the production and circulation of translations across the English Channel. I thus hope to uncover transnational networks of ideological, political and cultural transmission 
which are interconnected with the culture of printed translations in early modern England. I suspect there were other Catholics who drew on the queen's religious affiliations to build their professional networks and benefit socially, financially or politically from connections to her court. The corpus of translations into English printed between 1625 and 1642 and dedicated to Queen Henrietta Maria, Charles I and their close circles will likely continue to reveal the influential role of the queen's network and of the queen herself as agents who imported French culture into the British Isles.

I set out in this paper to demonstrate that certain tools were crucial in order to understand the role played by translation at and around the English court of Queen Henrietta Maria. These were bibliographical tools such as digital catalogues documenting liminal materials and paratexts of source texts and target texts (RCC, CCC, EEBO and Gallica), as well as biographical and network analysis tools (ODNB and 6DFB). Conjointly with an appropriate historical, political, religious and cultural contextualization, these tools proved necessary to analyse the case study of early modern English translator Thomas Hawkins, as they provided essential information allowing for a holistic understanding of his translation of The Holy Court. The combined data from these tools allowed for a preliminary analysis of Thomas Hawkins's place in the transnational Jesuit print network, and contributed to affirming his role as a translating agent.

\section{References}

Adolph, Anthony R. J. S. (Jan 2008) "Hawkins, Sir Thomas (bap. 1575, d. 1640?)." Oxford Dictionary of National Biography. Oxford, Oxford University Press. Available at: <http://www.oxforddnb.com/view/ article/12681>.

Agence bibliographique pour l'enseignement supérieur (ABES) (s.d.). "Chappelet, Sébastien (1589-1647)." ID Ref. Identifiants et Référentiels pour l'enseignement supérieur et la recherche. Available at: $<$ http://www.idref.fr/031111602>.

Backer, Augustin de, Alois de Backer and Charles Sommervogel (1869). "Caussin, Nicolas." Bibliothèque des écrivains de la Compagnie de Jésus ou notices bibliographiques 1-De tous les ouvrages publiés par les membres de la Compagnie de Jésus depuis la fondation de l'ordre jusqu'à nos jours; 2- Des apologies, des controverses religieuses, des critiques littéraires et scientifiques suscitées à leur sujet. Tome I $A-G$. Liège/Paris, Collège S. Servais et Institution Sainte-Geneviève, pp. 1143-1153. 
Bailey, Rebecca A. (2009). Staging the Old Faith: Queen Henrietta Maria and the Theatre of Caroline England, 1625-42. Manchester, Manchester University Press.

Bassnett, Susan (1998). "The Translation Turn in Cultural Studies". In S. Bassnett and A. Lefevere, eds. Constructing Cultures: Essays on Literary Translation. Clevedon, Multilingual Matters, pp. 123-140.

Belle, Marie-Alice and Brenda M. Hosington (2017). "Translation, History and Print: A Model for the Study of Printed Translations in Early Modern Britain.” Translation Studies, 10, 1, pp. 2-21.

Boutcher, Warren (2015). "From Cultural Translation to Cultures of Translation? Early Modern Readers, Sellers and Patrons". In T. Demetriou and R. Tomlinson, eds. The Culture of Translation in Early Modern England and France, 1500-1660. New York, Palgrave Macmillan, pp. 22-40.

Brooks, James. F., Christopher R. N. DeCorse and John Walton, eds. (2008). Small Worlds: Method, Meaning, and Narrative in Microbistory. Santa Fe, School for Advanced Research Press.

Buzelin, Hélène (2005). "Unexpected Allies: How Latour's Network Theory Could Complement Bourdieusian Analyses in Translation Studies". The Translator, 11, 2, pp. 193-218.

Callon, Michel (2006). "Sociologie de l'acteur réseau." In M. Akrich, M. Callon and B. Latour, eds. Sociologie de la traduction. Textes fondateurs. Paris, Les Presses Mines, pp. 267-276.

Caussin, Nicolas (1653). La Covr Sainte dv R. Pere Nicolas Cavssin, de la Compagnie de Iesvs. Mise en vn bel ordre avec vne notable augmentation des Vies de personnes illustres de la Cour, tant du vieil que du nouneau Testatement. Et autmentée en cette derniere Edition de la vie de l'Autheur, E de diuerses Histoires. Tome Second. A Paris, Chez Denis Bechet, ruë Saint Iaques, au Compas d'or, E̋ à l'Escu au Soleil. M. DC. LIII. Avec privilege, et approbation. Available at: <http://gallica.bnf.fr/ ark:/12148/bpt6k96105149?rk=21459;2>.

Clarke, Danielle (1998). "The Iconography of the Blush: Marian Literature in the 1630s." In K. Chedgzoy, M. Hansen and S. Trill, eds. Voicing Women: Gender and Sexuality in Early Modern Writing. Edinburgh, Edinburgh University Press, pp. 111-128.

Clarke, Danielle (2001). The Politics of Early Modern Women's Writing. Harlow, Longman.

Coldiron, Anne E. B. (2015). Printers without Borders: Translation and Textuality in the Renaissance. Cambridge, Cambridge University Press.

Demetriou, Tania and Rowan Tomlinson (2015). The Culture of Translation in early Modern England and France, 1500-1660. New York, Palgrave Macmillan. 
Early English Books Online (EEBO). Chadwyck-Healey. Available at: $<$ http://eebo.chadwyck.com/home>.

Eisenstein, Elizabeth (1979). The Printing Press as an Agent of Change. Communications and Cultural Transformations in Early Modern Europe. Cambridge, Cambridge University Press.

Hackett, Helen (2013). A Short History of English Renaissance Drama. London/New York, I.B. Tauris. Available at: <http://public.eblib. com/choice/publicfullrecord.aspx? $\mathrm{p}=1676092>$.

Harris, Carolyn (2016). Queenship and Revolution in Early Modern Europe: Henrietta Maria and Marie Antoinette. New York, Palgrave MacMillan.

Hawkins, Thomas (1626). The Holy Court or The Christian Institution of Men of Quality. With Examples of those, who in Court haue flourished in Sanctity. By Nicolas Caussin of the Society of Jesus. Written in French and Translated into English by T.H. At Paris. Anno Dom. M. DC. XXVI. Early English Books Online. Copy from University Library Cambridge.

Hawkins, Thomas and Others (1650). The holy court in five tomes: the first, treating of motives, which should excite men of qualitie to Christian perfection. The second, of the prelate, souldier, states-man, and ladie. The third, of maxims of Christianitie against prophanesse, divided into three parts, viz. divinitie, government of this life, E state of the other world. The fourth, containing the command of reason over the passions. The fifth, now first published in English, and much augemented according to the last edition of the authour; containing the lives of the most famous and illustrious courtiers; taken out of the Old and New Testament, and other modern authours. Written in French by Nicholas Caussin, S.J. Translated into English by Sr. T.H. and others. London, Printed by William Bentley, and are to be sold by John Williams, in Pauls Churchyard. Early English Books Online. Copy from University of Illinois (Urbana-Champaign Campus).

Hosington, Brenda M., ed. (2011). Renaissance Cultural Crossroads Online Catalogue of Translations in Britain 1473-1641. Available at: <www. hrionline.ac.uk/rcc/index.php>.

Hosington, Brenda M. (2015a). "Introduction: Translation and Print Culture in Early Modern Europe.” Renaissance Studies, 29, 1, pp. 5-18.

Hosington, Brenda M.(2015b). "The Role of Translations and Translators in the Production of English Incunabula." In S. K. Barker and B. M. Hosington, eds. Renaissance Cultural Crossroads. Translation, Print and Culture in Britain 1473-1640. Leiden/Boston, Brill, pp. 3-20.

Lefevere, André (1992). Translation, Rewriting, and the Manipulation of Literary Fame. London, Routledge. 
McCabe, Richard A. (2016). "Ungainefull Arte": Poetry, Patronage, and Print in the Early Modern Era. Oxford, Oxford University Press.

Norbrook, David (1999). Writing the English Republic: Poetry, rhetoric, and politics, 1627-1660. Cambridge, Cambridge University Press.

Paloposki, Outi (2010). “The Translator's Footprints.” In T. Kinnunen and K. Koskinen, eds. Translators' Agency. Tampere, Tampere University Press, pp. 86-107.

Piqué, Barbara (2007). "De l'histoire exemplaire à la galerie: 'les reynes et dames' de la Cour sainte.” In S. Conte, ed. Nicolas Caussin: rhétorique et spiritualité à l'époque de Louis XIII. Actes du colloque de Troyes (16-17 septembre 2004). Berlin, Lit Verlag, pp. 121-133.

Silva, Andie (2016). "Mediated Technologies: Locating Non-Authorial Agency in Printed and Digital Texts." History of European Ideas, 42, 5, pp. 607-617.

Thuillier, Guy and Nicolas Caussin (1998). "Un moraliste sous Louis XIII : La Cour sainte du P. Caussin." La Revue administrative, 51, 306, pp. 714-722.

Tymoczko, Maria (2007). Enlarging Translation, Empowering Translators. Manchester, St. Jerome.

Warren, Christopher, Daniel Shore, Jessica Otis, Scott Weingart and John Ladd (s.d.). Six Degrees of Francis Bacon. Available at: <www. sixdegreesoffrancisbacon.com>.

Warren, Christopher, Daniel Shore, Jessica Otis, Lawrence Wang, Mike Finegold and Cosma Shalizi (2016). "Six Degrees of Francis Bacon: A Statistical Method for Reconstructing Large Historical Social Networks." Digital Humanities Quarterly, 10, 3, n.p. Available at: $<\mathrm{http} / / /$ digitalhumanities.org/dhq/vol/10/3/000244/000244.html >.

White, Adam (2004). "Evesham, Epiphanius (fl. 1570-c. 1623).” Oxford Dictionary of National Biography. Oxford, Oxford University Press. Available at: < https://doi.org/10.1093/ref:odnb/37402>.

White, Michelle A. (2006). Henrietta Maria and the English Civil Wars. Aldershot, Ashgate.

\section{Marie-France Guénette marie-france.guenette.1@umontreal.ca}

